\title{
Suggestions for Critical Awareness, Accountability, and Transformation in Human Rights Education
}

\author{
William J. Foley Jr. \\ Teachers College, Columbia University
}

\begin{abstract}
Human Rights Education exists as an implementing entity of the Universal Declaration of Human Rights. Scholars such as Andre Keet and others have criticized the dissemination of universal rights through education because it covets Western ideology over local ethical and epistemological constructs. Using Tibbitts' revised typologies of Human Rights Education, this paper offers suggestions for critical pedagogy for the teaching of, for, and through Human Rights. These suggestions are drawn from examples of critical practice from throughout the world.
\end{abstract}

\section{Introduction}

Human Rights Education (HRE) is a powerful, if nascent, institution that is spreading throughout the world as a crucial piece of the Human Rights framework (Russell \& Suárez, 2017). This rapid dissemination across education requires that practitioners and researchers critically evaluate the purpose, pedagogy, and power that creates HRE. Curriculum is often guided by the legal standards of the state that is implementing education, this formulates the basis of many national curricula. HRE differs from other curricula in that it is set by law to instruct people on the multinational parameters from which other laws should stem. Entrenched in the Universal Declaration of Human Rights (UDHR), HRE propels itself and the document it derives from as a normalizing function. The teaching of human rights is a legal mandate that ensures compliance with the standards outlined by international law. The legal presuppositions of the UDHR offer the risk that its prescriptions are not suitable for every context. Indeed, it is arguable that the UDHR is a tool for Western political and (especially through HRE) epistemic hegemony (Keet, 2014). Thus, HRE may purport learner-agency through the dissemination of the Rights enshrined by law, while actually enhancing the control of Western ideologies over local beliefs (Keet, 2014). The risk for HRE to promote hegemony has sparked an interest in disruptive and critical HRE pedagogies that seek to redress power structures through activism and teaching.

A critical evaluation of HRE may begin by analyzing why HRE is taught. Tibbitts and Fernekes (2011) point out that HRE is specifically to promote the UDHR. The uniqueness of HRE is that it does not find its origins the nation-state. The ideology that UDHR represents is not exclusive to one place, but sprawling method for asserting what Keet (2015) recognizes as very specific interests. Those interest are spelled out in the UDHR (1948) which states: "every individual and every organ of society (...) shall strive by teaching and education to promote respect for these rights and the freedoms and by progressive measures, national and international, to secure their universal and effective recognition and observance" (page). This preamble clearly articulates that signatories to the Declaration are charged with education for the sake of the legal rights that are so enshrined. The UDHR (1948) admits that there is a need to teach 
about Human Rights making it a demand for a specific curricular focus. It seems assumed that the protection of the rights as enumerated rests on the ability of people to know what they are and to know that they can want to demand them. These interests have very real mechanisms that use HRE to promote the UDHR. While schooling is often a tool wielded through power to assert commonalities across the nation state, the UDHR had many levers through which HRE flow. The United Nations Educational, Scientific and Cultural Organization (UNESCO), Amnesty International, the Organization or Security and Co-operation in Europe (OSCE) and others, have all committed themselves to HRE (OSCE / ODHIR, 2012). The diversity of these speak to Keet's (2015) recognition that Human Rights intertwine power, legal authority, and knowledge through many different bodies.

In the purpose of HRE lies the problem. If the concept that is Human Rights is indeed universal, then why do people need to be educated on it? It is hard to argue that the UDHR finds it itself in a singularly agreed-upon moral compass. At the time of the creation of the UDHR, the American Anthropological Association wrote it was a "statement of rights conceived only in terms of the values prevalent in Western Europe and America" (American Anthropological Association as cited by Nickel, 2019). An original draft for the Arab Charter on Human Rights was first published in 1994, and later adopted by member states in 2004, out of a desire for a framework more rooted in Islam that is incompatible with the UDHR. The African Charter on Human and Peoples' Rights was brought to bear in the 1980s. This Charter's emphasis on "peoples" in the plural form is a sharp difference with the UDHR. The UN's own website remarks on the reservation that delegates from China had when discussing the idea of universal and individual rights (United Nations, 2021). Since the UDHR there have been additional documents required to extend rights to people who have not been afforded them. The specific rights and protections necessary for disabled people, Indigenous communities, and children were not initially included in the Universal Declaration. Not all other modifications have been welcomed. During the 1993 World Conference on Human Rights in Vienna several states moved for a more culturally relevant UDHR which was met with a statement reinforcing the supremacy of the original document. The consensus that the UDHR portends is not truly universal. Instead, Human Rights was set forth as something that the World as a political body is meant to gather around in legal and philosophical consensus. The universality lies only in the accord between nations and between a nation and the document. For there to be human rights, they needed to be written, agreed upon, and adopted. The need for declarative consensus-driven statements on Human Rights make it impossible for them to be truly a priori.

This paper begins by recognizing that since Human Rights are not a priori they cannot really be universal. Human Rights are just as much a construct as gender binaries and state borders. Tibbitts' (2017) analysis for different HRE modalities provide a structure by which the critiques of Keet (2017) and others can be furnished in critical educational contexts. Along with Tibbitts' modalities this paper also uses Bloom's taxonomy to leverage commonplace pedagogical training to extend access to practitioners seeking to implement Critical Human Rights Education (CHRE). This paper offers some ideas for how HRE can deconstruct Universal Human Rights while still promoting human dignity and outlines the potential for best practices across various contexts. 


\section{Literature Review}

Tibbitts (2017) suggests three typologies of Human Rights Education that practitioners implement in the field. These typologies are the typical practices for instructing about, through, and for human rights. They can also be useful for articulating how HRE may or may not be critical. Tibbitts first suggests an Awareness Model that usually presents Human Rights in formal education as a content centered mode sponsored by governments. This type usually targets schools and the students in these schools, seeking to provide direct instruction about what Human Rights are, and towards the history of the UDHR (Tibbitts, 2017). The second model in Tibbitts' typology is the Accountability or Professional model. Usually offered by both governments and civil society actors and aimed at developing the skills of professionals to ensure the protection of Human Rights within their fields. A typical, but not exclusive example, is the idea of training law enforcement in the protections afforded to all people under the UDHR. Many other professions such as teachers, doctors, and civil servants - amongst others - all demonstrate the ability to increase their application of Human Rights with such training (Tibbitts, 2017, p. 87). The final model presented is the Transformation Model; this model is aligned with Freirean Critical Praxis and aims to empower learners to recreate social change that is more aligned with the legal prescriptions of the UDHR (Tibbitts, 2017, p. 91).

Each of these typologies is a method for instructing learners on some aspect of the UDHR. Theses typologies indicate how HRE is more than just the teaching of the meaning, parameters, and potential for the UDHR. This is especially true of the Awareness Model which is typically situated in formal educational settings (Tibbitts, 2017). The Awareness Model teaches about Human Rights and seeks to disseminate information about the UDHR. Keet (2014) argues that Human Rights act as a tool to replace local notions of right and wrong with globally dominant ones; proposing that "if hegemony is taken to mean the manufacturing of consent, which is constructed around floating signifiers, human rights discourse can then certainly be regarded as hegemonic" (Keet, 2014, p. 48). HRE, along with any education that is intended to disseminate and promote attention to a particular cannon, would share in the interests of the same bodies from which that cannon derives. Simply put, if the national curriculum tends to promote the affairs of the nation and is implemented by national actors; than international curriculum would promote and be enabled by interests of powerful inter- and multinational actors. The hegemony that HRE proposes is not bound by any kind of border nor even ideology. Both Capitalist and Communist nations alike are signatories to the UDHR. This adulation of the UDHR as a global force for good sets it as a virtue that bears political capital that HRE constructs through its curricular presentation as an unquestionable fund of knowledge (Keet, 2014).

The Accountability Model as posited by Tibbitts can be used loosely to teach through Human Rights because the Accountability Model is usually intended for professionals that are obligated to secure individuals' rights, (Tibbitts, 2017). Thus, this model might be seen as teaching through Human Rights because it defines how learners are intended to meet their professional obligations and serve their clients. Keet and Zembylas (2011) both emphasizes how human rights can reconstruct harmful power relations and agree on the need for new models (Zembylas, 2011). This interpretation is usefully juxtaposed against with the Accountability Model because this model localizes Human Rights as a significant professional standard. As Zembylas (2017b) points out this kind of standard 
rarifies how Human Rights embodies and fulfills a Western framework to act as a colonizing mechanism. In the author's words, "( $\mathrm{t})$ he human rights regime is embedded within a specific cultural and historical framework involving the foregrounding of Western colonial knowledges" (Zembylas, 2017b, p. 488). Human rights are an entity that self-promotes Western ideology through setting standards such as those for professionals. In part, the argument against the UDHR as a global standard is in the hegemony of centralizing decisions over right and wrong, but Zembylas (2017a) also offers several logical arguments against globalizing HRE as a set of standards. First, that the colonial knowledges were often responsible for harm being caused in the first place and are thus not fit to be the standard bearer for good (Zembylas, 2017a). Moreover, Zembylas (2017a) argues that concepts of human dignity are entirely contrived from the individual and social fabric of peoples, not in axiomatic statements. A singular professional or ethical standard is simply not enough for the world over because we all describe the world in different realities. In structuring a decolonial HRE, Zembylas (2017) inserts several dimensions drawn from the seminal work of Tuck and Wang (2012). Zembylas describes that decolonial HRE must be critical of the current historical, political, and material situation of learners, it must implement tangible decolonial processes, and center the human rights ethic on individual and collective emotions (Zembylas, 2017b). Additionally, a decolonial HRE would also make note of the particular social relations in a context (Zembylas, 2017b).

Tibbitts final model is the Transformation or Activism Model, the latter name was added later to better specify what this type intends (Tibbitts, 2017). This model teaches for Human Rights because it seeks to transform society using the UDHR as a standard for justice (Tibbitts, 2017). The Transformation Model is arguably the most critical as Tibbitts (2017) aligns it with Freirean Praxis. Nonetheless, in using Human Rights discourse as the standard for transformation the aforementioned power structures are re-implemented. Ahmed (2017) argues that HRE does not have to reproduce hegemony and that transformation can occur outside of legal parameters. Defining a disruptive HRE that does not fit into previous categories, Ahmed (2017) argues that HRE can be used to systematically transform power relations though this must often be done outside of legal norms. In this view transformation may not be reliant on the standards of the UDHR. Bajaj (2008) highlights some notions of critical peace education where "the transformation of educational content, structure, and pedagogy is to address direct and structural forms of violence at all levels" (p. 135). Structural violence is physical as well as epistemic and symbolic harm that can be implemented by oppressive curriculum. Because formal education settings are typically the province of the state and elite actors, Bajaj (2008) argues that peace education should likely happen outside of school. Likewise, CHRE would also benefit from separation from formal structures embedded with power, or at least within formal settings that provide space for the open critique of power. Critical peace education shares some similarities with Ahmed's (2017) Chilean example, discussed above, in that it is entirely participatory. Both examples also require some measure of learning to happen outside or even against power structures. 


\section{Repositioning HRE}

Tibbitts' (2017) typologies are a useful lens by which to consider reforming HRE. Since these typologies are drawn from the field, they outline the typical modes by which HRE is currently happening. Instead of attempting to rebuild HRE from the ground up, it is possible to use Tibbitts' (2017) typologies as an inroad into critique and critical praxis. Additionally, these models are simultaneously congruent with Bloom's (1956) taxonomy which helps to make them more approachable for educators. Awareness is structured at the bottom of Bloom's (1956) taxonomy, the most basic form of learning: remembering and understanding, specifically for the UDHR. Accountability exists in the middle phases: apply and analyze, used in HRE to specify how the Human Rights are applicable to specific situations such as careers. The final stages are to evaluate and to create, which share similarities with the traditional Transformation model wherein leaners are empowered to critique and re-create their specific contexts to better implement Human Rights. These typologies provide a possible blueprint for theorizing and implementing CHRE. Using these typologies to teach about, through, and for Human Rights may be amended for criticality into: 1) impart an understanding of the current political, economic, social, and historic reality of learners' context, 2) enfranchise learners to hold state structures and power-holders accountable to the Human Rights model so as to ensure a minimal legal framework to exist peacefully and analyze current power structures, and 3) enable learners to transform societies they live in from the current human rights model to a locally constructed model. Below are possible methods for these renewed objectives

\section{The Awareness Model}

The first learner objective could be situated within the Awareness Model. Traditionally this model is used to teach about human rights as legality and theory often in a formal setting that relies solely in the UDHR as the bulwark of the curriculum. This typology might include utilizing curriculum from UNESCO or UNICEF that operate within the HRE guidelines proposed by the United Nations. Other international NGOs and scholars have also proffered an array of curricula aimed at teaching about the UDHR and human rights theory. This is largely not critical because the traditional Awareness Model reinforces the prominence of the UDHR by making it the purpose of a learning unit. Treatment of Human Rights through curriculum presents it as an immutable truth that is being handed to students for them to remember. Keet (2014) argues that to be critical HRE must not make declarative statements about what is or is not a right. When integrating Human Rights into standardized curriculum it becomes such a statement. Treating the UDHR as canonical reifies it as an iconoclast standard that must be adhered (Keet, 2014), akin to math or science.

Gibson and Grant (2017) offer Brayboy (2011)'s concept of genesis amnesia as an entryway into critical instruction. Genesis amnesia describes the presentation of opinion through curricula by the powerful as to present those opinions as fact (Solyom \& Brayboy, 2011). Oftentimes, students may suggest that the world simply "is the way it is," without having the tools to recognize that contexts do not exist in a vacuum. Gibson and Grant (2017) point out that the language of HRE can be intentionally used alongside history to promote justice. As Gibson and Grant (2017) suggest, "one of our primary challenges as social justice and human rights educators is to get our students to see the water in which they swim" (p. 225). Here, learners are meant to learn the history of their oppression and how it circumscribes the present. Historicizing HRE - 
or infusing the curriculum with the historical conditions that have led up to the present - unmoors learners' material conditions away from determined truth and repackages them as situational realities. This kind of criticality is nestled within the application of knowledge. Instead of teaching history in an abstract way, linking history to the lived experiences of the learners connects them with the past. These links are important learning tools that integrate lessons into our individual schema.

Some examples emerge as critical methods for the Awareness Model. The Zinn Education Project (2019) is a collaborative effort between two NGOs rooted in the work of the Historian Howard Zinn who authored the alternative "Peoples' History of the United States." The Zinn Project (2019) seeks to engage students in "the empowering potential of studying U.S. history [that] is often lost in a textbook-driven trivial pursuit of names and dates. People's history materials and pedagogy emphasize the role of working people, women, people of color, and organized social movements in shaping history". Teaching Tolerance (TT) is a project of the Southern Poverty Law Clinic in the United States. TT crowd sources materials from journalists, authors, and educators aimed at "social justice and anti-bias. The anti-bias approach encourages children and young people to challenge prejudice and learn how to be agents of change in their own lives", which is done through four area standards of social justice (Teaching Tolerance, 2019). Facing History is another example which utilizes alternative modes for history instruction to present critical pedagogy in the classroom (Facing History, 2019). Their model relates history to students' lives to promote diversity and teach towards "about racism, antisemitism and prejudice" (Facing History, 2019). Each of these examples come from the United States (US) and are grounded in promoting democratic citizenship specific to the US context.

Curriculum sets are not the only means by which to approach critical instruction around history, social conditions, and rights. A school in the United States also provides an example of utilizing critical pedagogy to raise awareness of oppression. El Puente academy uses a critical curriculum that merges traditionally disparate disciplines to link historic constructs to modern consequences (De Jesus, 2003). Their ideology is based on the principle of Sankofa (De Jesus, 2003), an Akan tribe word that loosely translates into a study of history as to not lose the past (Berea College, 2019). Students at El Puente did not learn historical facts in a vacuum. Project Based Learned (PBL) incorporates facets of the local community into the classroom such as trip to local factories that are now abandoned alongside studies of economic policies that were implemented and led to the decline of manufacturing in the region. Student concepts self-drove some of the inquiry. One student reported learning the difference between being Hispanic versus Latino; and how it was empowering to understand their cultural community better (De Jesus, 2003). These are also relevant historical and political distinctions that complicate oppression and class distinctions in concert with racial constructs. Consequently, Students reported learning about more than just history, but also about their own identities (De Jesus, 2003). These examples are not universally applicable, though they are still samples of critical pedagogy specifically centered around teaching students about the history of oppression. Each of these bring to the center the voices of oppressed communities while providing space for students and teachers. 


\section{The Accountability Model}

The Accountability Model typically consists of older professionals and learners holding trainings that are sponsored by civil society or governments (or both) to leverage their professional duties in upholding human rights (Tibbitts, 2017). Tibbitts does not explicitly deny students and classrooms this model but observes that it is more commonly found among adult professionals. Already the Accountability Model offers some vision of criticality. CHRE might even evolve the Accountability Model by folding the other traditional typologies into it and expanding the model to young leaners. A Critical Accountability Model could bring awareness of the entitlements promised by the UDHR while empowering learners to hold power structures to those standards. The accountability is shifted from the learners' self-accountability. In this Accountability Model the UDHR is utilized specifically for the protection of the learner. This model still recognizes that the UDHR (and perhaps other rights models stated within the local context) may be a problematic standard, but a nonetheless useful one. This model is situated at the intermediate levels of Bloom's (1956) taxonomy: analyze and apply. The legal tenants of the UDHR are analyzed against the learner's context and applied for their fulfilment.

Tibbitts (2015) argues that HRE can have significant influence over the lives of adult learners and Critical Accountability can leverage this this influence. In studying HRE trainers in Turkey, Tibbitts (2015) notes that women were able to teach their children about the oppressive nature of certain gender roles. The same participants were also more likely to engage in the Women's movement in Turkey (Tibbitts, 2015). Learners were able to use the standards learned as part of their work to better their entire lives including their interpersonal relations with men and boys. The power structures that existed at all different levels of society were challenged by learners who had the agency to do the challenging. This example demonstrates how the Critical Accountability Model can actively support learners in oppressive contexts by giving them knowledge of the existing legal framework that can afford specific protections. However, this example also limits the Accountability model to adults that are likely already interested in Human Rights Work. Critical accountability is not limited to Human Rights workers or adjacent professionals. All people, including young learners, should be given the tools to hold power accountability in many situations.

Extending the Accountability Model to youth would entail participatory methods that promoted their abilities to question authority. The Freedom Schools of the Southern United States are one method for enhancing student autonomy and activism. During the 1968 Summer of Freedom, Black activists formulated a plan to provide genuine learning opportunities for members of their communities during the summer months when formal school was not in session. Activities worked together with educators to plan, develop, and implement curriculum that taught general academics, focused on civics, and intentionally taught equality (Perlstein, 1990). These schools trained young learners to be activists by guiding them through anti-racist work such as canvassing, protesting segregation, and singing freedom songs (Hale, 2011). The Freedom School model carries on in the United States today. One community freedom school in Washington, DC notes in their mission a specifically dual focus on academic excellence and community service through the same philosophy of nonviolence that the Civil Rights Movement was founded on (EW Stokes PCS, n.d.). The Children's Defense Fund also utilizes the Freedom School summer model for remedial education (Jackson 
\& Howard, 2014). These continue to be sites for Black student liberation in a country where segregation and disparity are still commonplace. In the Children's Defense Model educators are servant/leaders. The camps' teachers utilize a pedagogy that empower learners to be active participants in the entire camp experience (Howard, 2016). The curriculum continues to center Civil Rights which has produced among students an increased desire to engage in their community, in civil society, and to have greater interest in their academics (Howard, 2016).

Both the Freedom Schools as well as the HRE trainers in Turkey are examples of how educational settings can be used to hold power structures accountable. They also relate Ahmed's (2017) uses the Chilean Student Movement of 2017 to indicate how educative experiences grounded in rights can disrupt power structures. Ahmed's example is certainly educative, but less grounded in the UDHR - students were protesting initially against increased transit costs. Though outside the legal concept of the UDHR increased fares that would have made attending school difficult decreased Chilean students' access to their right to and education. Similarly, the above examples may not seek to educate towards the UDHR specifically, but they do note how the educating towards rights and equality can secure Human Rights if there are also demands made of authority. These examples discuss how a human rights model can be used to help learners become agents of accountability. Freedom Schools were a demonstration of the right to an education. They also encouraged students to be activist for their other US civil rights many of which are comparable to the UDHR. Educating trainers and learners in their rights enabled them to hold their families, societies, and more accountable.

\section{The Transformation Model}

The Transformation Model could be considered linked to social justice as critical pedagogy is integral to this model's stated outcome which is activism. Typically, learners work alongside instructors to critique power structures to advocate for justice. In some ways the traditional Transformation model is like the Critical Accountability model. The servant leadership/educator role of the Freedom Schools is usual in the Transformation Model. Learners and educators are voluntary participants that are engaged in Human Rights work that challenges the status quo. In some ways the Transformation Model is the enactment of the call for Human Rights to be globalized through the various facets of society (Tibbitts, 2017). Evidence from the field suggests that the intent of this model is to "incorporate a critical stance towards features of one's own society, the nature of power/authority, and even the human rights system itself" (Tibbitts, 2017 p. 91). Here, it is suggested that the separate areas of critique are delineated across typologies. Critique of power structures and authority is reserved for the Critical Accountability Model where learners hold authority responsible. In the Critical Transformation Model, critique of the human rights system becomes the nexus of programming. In so doing the Transformation model links to the final stages of Bloom's Taxonomy. Learners are encouraged to evaluate Human Rights for their local applicability. After, they are charged with creating - or reinvigorating - a localized system.

This Transformation Model diverges from its previous format in its rejection of the UDHR. Critical Transformation logically follows the Accountability Model which relies on the UDHR as a minimum standard. This evolution from accountability to 
transformation is necessary because "the master's tools will never dismantle the master's house. They may allow us temporarily to beat him at his own game, but they will never enable us to bring about genuine change" (Lorde, 2007, p. 112). Lorde (2007) argues that a hegemonic foundation is not capable of truly challenging oppression. A different ethos is required to facilitate liberation. Even meeting the basic standards of the UDHR is likely improbable if they are strictly defined by one positionality. Stavenhagen (2008) notes how countries that have promised to meet the standards of the UDHR for all their citizens are often still unable to do so. In part, systems meant to enable rights are assimilative and not liberative. That is if the bedrock of the benefit [in Stavenhagen's (2008) perspective this benefit is the right to education] is hegemonic then any attempts to grow that benefit will also be hegemonic. Many Indigenous students, for example, attend compulsory schools that technically afford them the Right to Education while actually disenfranchising them. As an alternative, Stavenhagen (2008) points to Canada where "the First Nations and the Inuit have the option of establishing their own education programmes and exercise control over primary and secondary schools, ( $\mathrm{p} 127)$. In these environments what constitutes a right to education is challenged. These schools offer programming that respects Indigeneity, including multi-lingual instruction that opens the potential for competing epistemological views (Stavenhagen, 2008). They create environments where the normative right to an education is challenged with alternative systems. The right to education is no longer strictly defined as equal opportunity for success within the formal systems parameters.

New York City, United States, provides an example of critical transformation. New York City is one of the most diverse cities in the world and reflects the broader US migrant identity. In the US the Right to Education is often stylized as teacher-led schooling that embraces hierarchical features such as principals, policies, and a particular student/teacher relationship. In New York, this often means that minoritized, immigrant, and other students are subject to authorities that do not come from or represent their communities. Humanities Preparatory Academy (HPA) serves students that have failed in other schools and is largely Latinx population of students that are migrant or the descendants of migrants, as well as other students who in the US would be identified as people of color and are thus marginalized (Hantzopoulos, 2011). The academy has instituted a number of practices that create heterarchical systems for all community members. One physical implementation is the removal of the commonplace teacher workroom which is a space that permits teachers to separate themselves from students for privacy and work. This separation epitomizes the hierarchical relationship between teachers as representative of sanctioned knowledge and student as object that requires teaching. At HPA there is one space where both professionals and learners come together (Hantzopoulos, 2011). In the "hub" both learners and educators share space and resources to meet their common goal of working for the community (Hantzopoulos, 2011). These contrasts typical schooling in the United States which features hierarchy and curriculum implementation. Significantly, the space functions as the metaphoric heart of the institution. That is, the most radical space - where the hierarchy is leveled - is where all the community members must themselves work. The critical transformation model could leverage spaces like this. In such spaces, ideas are also able to be equalized alongside bodies. 
Critical transformation implies creation, and that creativity needs space. These spaces need to be able to recognize alternative concepts of right, wrong, and reality. De Sousa Santos (2012) argues that the Pluriversity challenges dominant schemas with subaltern epistemologies. Pluriversities recognize that the sources of the UDHR are not in a moral position to teach the world because of their history of domination. One feature of the Pluriversity is the elevation of marginalized epistemologies with a focus on how they contrast and oppose dominant paradigms (Martinez-Vargas, 2020). The "plural" is quite literal. Viewpoints meet in conversation and do not seek to converge or aspire to acquiesce. In these settings Martinez-Vargas (2020) argues that participatory research is integral to maintain a plurality of positions. In participatory research the agenda is derived from the community. Instead of researcher and object, the members who engage research are also the studied. Localizing human rights is an analogous project. The creation of community standards for right and wrong need to be determined by the members of the community that those rules govern. The creation process is equally participatory in this concept. Beginning with the deconstruction of the UDHR by participants, the community can then move forward with analyzing the value of the UDHR's tenants in their own context. Following evaluation, the community can create their own standards for the preservation of human dignity. This may require some convergence, but the many voices of the Pluriversity represent various communities who can independently create their concepts. The Pluriversity through its participatory nature offers space to legitimize questioning the Human Rights system much as Tibbitts indicated the traditional Transformation Model could.

\section{Conclusion}

The traditional teleology of Human Rights Education perpetuates a hegemonic brand that stems from a certain positionality's concept of justice. The UDHR is grounded in Western ontology with little credence to the world at large. This paper has presented numerous critiques of the traditional Human Rights system as well as HRE. Using Tibbitts' (2017) typologies this paper was able to identify possible methodological shifts within standing HRE practice. Bloom's (1956) taxonomy is infused as a scaffold for educators trained in Western pedagogy to understand the typologies as shifting towards a vertical process of liberation. These suggestions are not definitive, nor do they seek to be prescriptive. Such intent would ultimately recreate the same ethos of certitude of one value statement over another. These examples highlight the possibility of a course correction. Human Rights educators, as with most teachers, center their work on the care for justice that the UDHR has always intended. Beginning with that cause, these educators can push the boundaries of HRE. Locating our work within the traditional and critical typologies is a place for educators to begin. From there, using the critiques above educators can evaluate their own programming for its liberative potential. Ultimately, the work of pushing HRE forward will only be partially done through theorizing. Educators and learners will bear the burden of challenging traditional HRE in their domains. This paper hoped to have offer some ways for those challenges to happen.

Will Foley is a special education teacher at a public international school in Washington DC. He is pursuing graduate studies at Teachers College in the department of International and Transcultural Studies. He is interested in curriculum studies. 


\section{References}

ALICE CES. (2012, September 28). Boaventura de Sousa Santos - Spaces of transformation: Epistemologies of the south.

https: / / www.youtube.com/ watch?time_continue=6\&v=UzecpSzXZOY\&feat ure $=$ emb_logo

Arab Charter of Human Rights (1994). Cairo, Egypt. http:/ / www.humanrights.se/ wp-content/ uploads / 2012/01/ Arab-Charteron-Human-Rights.pdf

Ahmed, A. K. (2017). Disrupting power/entrenching sovereignty: The paradox of human rights education. Prospects, 47(1-2), 3-16.

Amnesty International (2017). The whole school approach (pp. 5-9) and tools and templates (pp. 28-37). In Human Rights Friendly Schools Toolkit. London: Amnesty International.

http: / / www.amnesty.org/en/library / asset/POL32/001/2012/en/7b237c0f6568-41dd-9fdd-d60817e88f77/ pol320012012eng.pdf

Bajaj, M. (2008). Critical peace education. Encyclopedia of peace education, 135-146.

Berea College. (2019). The power of Sankofa: Know history. The Carter G. Woodson Center. https: / / www.berea.edu/cgwc/the-power-of-sankofa /

Bloom, B. S. (1956). Taxonomy of educational objectives. Vol. 1: Cognitive domain. New York: McKay, 20, 24.

De Jesus, A. (2003) 'Here's it more like your house': The proliferation of authentic caring as school reform at El Puente Academy for Peace and Justice. In B. Rubin \& E. Silva (eds.), Critical voices: Students living school reform (... ed., pp. 132-151). New York and London: Routledge.

El Puente. (2019). El Puente academy for peace and justice. https://elpuente.us/elpuente-academy-for-peace-justice

EW Stokes PCS (n.d.) About Us. EWStokes.org. https: / / www.ewstokes.org/about-us

Facing History. (2019). About Us. https: / / www.facinghistory.org/about-us

Gibson, M. and Grant, C. (2017). Historicizing critical human educational practices: A human rights framework for justice-oriented teaching. In M. Bajaj (Ed.) Human Rights Education: Theory, Research, Praxis (pp. 225-250). University of Pennsylvania Press.

Hale, J. (2011). "The student as a force for social change": The Mississippi freedom schools and student engagement. The Journal of African American History, 96(3), 325-347. 
Hantzopoulos, M. (2011). Institutionalizing critical peace education in public schools: A case for comprehensive implementation. Journal of Peace Education, 8(3), 225242.

Howard, T. C. (2016). Why black lives (and minds) matter: Race, freedom schools \& the quest for educational equity. The Journal of Negro Education, 85(2), 101-113.

Jackson, T. O., \& Howard, T. C. (2014). The continuing legacy of freedom schools as sites of possibility for equity and social justice for black students. Western Journal of Black Studies, 38(3), 155-162.

Keet, A. (2014a). Epistemic "othering" and the decolonization of knowledge. Africa Insight, 44(1), 23-37.

Keet, A (2015). It is time: Critical human rights education in an age of counterhegemonic distrust. Education as Change. 19(33), 46-64. DOI: $10.1080 / 16823206.2015 .1085621$

Keet, A. (2017). Does Human Rights education exist. International Journal of Human Rights. http: / / repository.usfca.edu/ijhre/vol1/iss1/ 6

Lorde, A. (2007). Sister Outsider: Essays and Speeches. 1984. Berkeley: Crossing.

Martinez-Vargas, C. (2020). Decolonising higher education research: from a university to a pluri-versity of approaches. South African Journal of Higher Education, 34(2), 112-128.

Meijas, S. (2017). Politics, power, and protest: Rights-based education policy and the limits of human rights education. In M. Bajaj (Ed.) Human rights education: Theory, research, praxis (pp. 170-194). University of Pennsylvania Press.

Nickel, J. (2019). Human rights. In E. N. Zalta (Ed.), The Stanford encyclopedia of philosophy.https: / / plato.stanford.edu/archives/sum2019/entries/rightshuman.

OSCE/ODHIR (2012). Guidelines for human rights education in secondary school systems (Warsaw: Organisation for Security and Cooperation in Europe) Section on Cm(39 pp). http: / / www.osce.org/odihr/93969

Perlstein, D. (1990). Teaching freedom: SNCC and the creation of the Mississippi freedom schools. History of Education Quarterly, 30(3), 297-324.

Russell, S.G., \& Suarez, D. F. (2017). Symbol and Substance: Human Rights Education as an Emergent Global Institution (pp. 19-46). In M. Bajaj (Ed.) Human Rights Education: Theory, Research, Praxis. Philadelphia: University of Pennsylvania Press.

Solyom, J. A., \& Brayboy, B. M. J. (2011). Memento Mori: Policing the minds and bodies of indigenous Latinas/os in Arizona. Cal. W. Int'l LJ, 42, 473. 
Stavenhagen, R. (2008). Building intercultural citizenship through education: A human rights approach. European Journal of Education, 43(2), 161-179.

Teaching Tolerance (2019). About teaching tolerance. https: / www.tolerance.org/ about

Tibbitts, F. (2015). Women's human rights education in Turkey: feminist pedagogy and trainer's engagement in social change. Journal of Peace Education, 13(1), 41-59. https: / / doi.org/10.1080/17400201.2015.1103722

Tibbitts, F. (2017). Evolution of Human Rights Education Models. In M. Bajaj (Ed.) Human Rights Education: Theory, Research, Praxis (pp. 69-95). Philadelphia: University of Pennsylvania Press.

Tibbitts, F., \& Fernekes, W. R. (2011). Human rights education. In S. Totten \& J. E. Pedersen (Eds.), Teaching and studying social issues: Major programs and approaches (p. 87-117). IAP Information Age Publishing.

Tuck, E., \& Yang, K. W. (2012). Decolonization is not a metaphor. Decolonization: Indigeneity, Education \& Society, 1(1). 1-40. https: / /jps.library.utoronto.ca/index.php/des/article/view/18630/15554

United Nations. (1948). Universal declaration of human rights. UN General Assembly, 302(2), 14-25.

United Nations. (2021). History of the document. https: / / www.un.org/en/sections/ universal-declaration/ historydocument/index.html

Zembylas, M. (2011). Peace and human rights education: Dilemmas of compatibility and prospects for moving forward. Prospects, 41(4), 567-579.

Zembylas, M. (2017a). Emotions, critical pedagogy, and human rights education (pp. 47-68). University of Pennsylvania Press.

Zembylas, M. (2017b). Re-contextualising human rights education: Some decolonial strategies and pedagogical/curricular possibilities. Pedagogy, Culture E Society, 25(4), 487-499.

Zinn Education Project. (2019). Why teach people's history. https: / / www.zinnedproject.org/why 